\title{
How Teachers' and Students' Mindsets in Learning Have Been Studied: Research Findings on Mindset and Academic Achievement
}

\author{
Junfeng Zhang, Elina Kuusisto, Kirsi Tirri \\ Faculty of Educational Sciences, University of Helsinki, Helsinki, Finland \\ Email: junfeng.zhang@helsinki.fi
}

How to cite this paper: Zhang, J. F., Kuusisto, E., \& Tirri, K. (2017). How Teachers' and Students' Mindsets in Learning Have Been Studied: Research Findings on Mindset and Academic Achievement. Psychology, 8, 1363-1377.

https://doi.org/10.4236/psych.2017.89089

Received: June 23, 2017

Accepted: July 18, 2017

Published: July 21, 2017

Copyright ( 92017 by authors and Scientific Research Publishing Inc. This work is licensed under the Creative Commons Attribution International License (CC BY 4.0).

http://creativecommons.org/licenses/by/4.0/

\begin{abstract}
Empirical research on mindset has indicated that mindset can predict numerous individual achievement, including academic, cognitive, motivational, affective and even socioeconomic, through mediation of social-cognitive approaches. The purpose of this paper is to compile and synthesize articles published from 1998 to 2017 on the relationship between mindset and academic achievement and explore the role of mindset in academic achievement. The studies indicate that students' mindsets play several roles of cause and mediator in academic achievement. Mindset can also be an outcome of students' academic achievement. Furthermore, in some studies, the relationship between mindset and achievement is non-correlational. Meanwhile, teachers' mindsets play the role of cause or mediator in students' academic achievement, but no role of outcome. Limitations and recommendations for future studies are discussed.
\end{abstract}

\section{Keywords}

Mindset, Student, Learning, Teacher, Academic Achievement

\section{Introduction}

This study summarises research on the relationship between mindset and academic achievement. It surveys how mindsets in learning have been studied in teachers and in students. The participants in the reviewed studies were teachers and students at various stages of education, ranging from elementary school to adult education. Academic achievement refers to students' academic performance in school, measured mainly by grades.

The term "mindset" in learning was officially proposed by Carol Dweck in 2006. Her theory of mindset is built on a positive psychology approach in which 
human intelligence is understood as a malleable quality. Dweck's earlier research (Dweck \& Bush, 1976; Dweck, Davidson, Nelson, \& Enna, 1978) on attribution of failure feedback could be regarded as the basis for the phrase "implicit theory of intelligence" (Dweck \& Leggett, 1988; Levy \& Dweck, 1999; Dweck, 2000), which later evolved into the concept of "mindset." In the two primary studies, students' attribution of failure feedback was divided into two categories: "solution-relevant or solution-irrelevant aspects" and "intellectual adequacy," which could be considered as an embryonic form of "fixed mindset" and "growth mindset." Dweck (2006) states that mindset "profoundly affects the way you lead your life" (p. 6). According to her definition, mindsets are beliefs that individuals hold about their most basic qualities and abilities. To have a fixed mindset (the entity theory) is to believe that human qualities are immutable; to have a growth mindset (the incremental theory) is the belief that basic qualities may be cultivated with effort.

Before the term "mindset" was proposed, Dweck (2000) had utilized the following concepts: implicit theories or implicit beliefs of basic human qualities, such as intelligence, ability, or personality. Although the phrase "implicit theory of intelligence" was generally used in studies over the past decades, recently, mindset has been used by an increasing number of scholars (Gutshall, 2013, 2014; O’Rourke, Haimovitz, Ballwebber, Dweck, \& Popovic, 2014; Esparza, Shumow, \& Schmidt, 2014). In current academic research, the meaning of "implicit theory of intelligence/ability" and "mindset" appears to be quite similar. In the present study, for the sake of convenience and uniformity, the term "mindset" will be used.

Previous reviews examining the relationship between students' mindsets and their performance indicate that mindset has an essential role in learning (Burnette, O’Boyle, VanEpps, Pollack, \& Finkel, 2013; Dweck, 2000, 2012; Tirri \& Kujala, 2016; Yeager \& Walton, 2011). Dweck and Leggett's (1988) social-cognitive approach to motivation and personality specified how individuals' implicit theories oriented them to set different goals and influenced their perceived ability, their cognitive and affective mechanisms, and their behavior patterns. Dweck's (2000) review of findings based on her 30 years' research illustrated that people's implicit theories not only affected their self-judgment and played an important role in their adaptive or maladaptive functioning, but also affected the way in which they judged and treated others. Dweck's (2012) later research indicated that a growth mindset could "advance conflict resolution between longstanding adversaries, decrease even chronic aggression, foster cross-race relations, and enhance willpower" (p. 614). By introducing the SOMA (setting/operating/monitoring/achievement) model into a quantitative synthesis of research collected from the year 1988 to 2010, Burnette, O'Boyle, VanEpps, Pollack, and Finkel's (2013) meta-analysis demonstrated that implicit theories predicted selfregulatory process, which in turn, predicted goal achievement. Specifically, goal setting, goal operating, and goal monitoring hold promise for linking incremental beliefs directly to goal achievement. 
By comparison, there is less research on the relationship between teachers' mindsets and students' achievement. However, intervention studies have demonstrated that mindset can be changed, and thus, students' academic achievement can be improved. After reviewing the theoretical basis of mindset interventions, Yeager and Walton (2011) concluded that the teachers' role could be potentially important, especially in interventions 'targeting students' subjective experience" (p. 267) in school, "developing powerful yet stealthy persuasive tactics" (p. 285) for conveying psychological ideas, and "tapping into recursive processes" (p. 267) in the educational environment. Furthermore, according to a number of studies these social-psychological interventions can produce longlasting gains in achievement. Tirri and Kujala (2016) reviewed brain research on mindset from the perspective of neuropsychological mechanisms, which indicated support for Dweck's theory: students' mindsets were adaptive and associated with their learning processes. Crucially, students could be influenced by appropriate interventions, since even "very brief intervention including knowledge on the value of effort and the potential for brains to adapt to new information has had a positive influence on students' learning" (p. 1236).

From previous reviews, we may conclude that, through the mediation of social-cognitive approaches, mindset can predict numerous aspects of individual achievement, including academic, cognitive, motivational, affective and even socioeconomic. However, those reviews on mindset seem to have some limitations. First, even though the reviews indicate that mindset affects learning, which is in line with Dweck's theory, they do not focus on academic achievement as measured by grades. Second, the nature of the approach is slightly singular and specific. For example, Burnette et al.'s (2013) meta-analysis provides a broad view of the relationship between self-regulation and mindset. However, in addition to quantitative studies, mindset has also been studied with qualitative and mixmethod approaches, yielding valuable information about mindsets in classroom interaction, especially in connection with teachers (see Rissanen, Kuusisto, Hanhimäki, \& Tirri, 2016). Thirdly, in previous reviews, mindset has mostly been regarded as an independent variable that predicts the dependent variable, which is achievement. However, the role of mindset could be investigated more broadly beyond "cause" alone.

In summary, previous research may lack a focus on the role of mindset in academic achievement. The purpose of the present article is to explore the role of mindset in students' academic achievement. The research questions are as follows:

Research Question 1: What is the role of students' mindsets in their academic achievement?

Research Question 2: What is the role of teachers' mindsets in students' academic achievement?

\section{Method}

The strategy for this review included electronic database searches and back- 
tracking references. An initial search was made using the following databases: SCOPUS, ERIC, and Google Scholar. Searched keywords included mindset, implicit theory, Dweck, fixed mindset, growth mindset, entity theory/belief, incremental theory/belief, and academic achievement. We then utilized references to backtrack additional potentially relevant articles that might have been lost in the electronic database search. 22 articles from 1998 to 2017 which studied "mindset" and "academic achievement" and thus met our inclusion criteria were chosen for our data, 17 of which examined students' mindsets in learning (Table 1) and 5 examined teachers' mindsets (Table 2).

\section{The Role of Students' Mindsets in Their Academic Achievement}

Based on our review, the role of students' mindset in academic achievement will be discussed from four perspectives: mindset as a cause of the academic achievement, mindset as a mediator, mindset as an outcome, and mindset without an evident role (Table 1).

\subsection{Mindset as a Cause}

The causal role of mindset means that in an educational context, students' mindset serves to affect their academic achievement, which is the finding in 13 articles. These studies include interventions that illustrate the powerful effect of mindset teaching in students' academic achievement among American primaryschool students (Mueller \& Dweck, 1998), American secondary-school students (Blackwell, Trzesniewski, \& Dweck, 2007; Good, Aronson, \& Inzlicht, 2003), and African-American college students (Aronson, Fried, \& Good, 2002). For example, after three sessions in which teachers advocated and taught a growth mindset and the malleability of intelligence to an African-American group, these students not only achieved higher grades, but also reported enjoying and valuing their academic studies more (Aronson et al., 2002). By comparison, in studies conducted among fifth graders in public elementary schools in the United States, Mueller and Dweck (1998) found that individual praise of students' intelligence weakened motivation and led to their low achievement.

The causal role of mindset in academic achievement was principally reflected through intermediate variables. A growth mindset predicted a higher achievement through the intermediate variables of goal setting (e.g., performance and learning goals), goal operation (e.g., helpless and mastery-oriented strategy), and goal monitoring (e.g., negative emotion and expectations) (Ahmavaara \& Houston, 2007; Fonseca et al., 2009; Leondari \& Gialamas, 2002). For example, in Greek studies by Leondari and Gialamas (2002) and a British study by Ahmavaara and Houston (2007), the causal role of mindset in achievement was realized through "perceived competence," which was regarded as an important variable linking mindset with achievement. These results were consistent with Dweck's (2000) conclusion that the impact of mindset was mediated by perceived performance. 
Table 1 . The role of students' mindsets in academic achievement.

\begin{tabular}{|c|c|c|c|c|c|c|c|c|}
\hline & \multirow{2}{*}{$\begin{array}{l}\text { Author } \\
\text { (year) }\end{array}$} & \multirow{2}{*}{ Title } & \multicolumn{3}{|c|}{ Sample } & \multicolumn{2}{|c|}{ Method } & \multirow{2}{*}{$\begin{array}{l}\text { Role of } \\
\text { Mindset }\end{array}$} \\
\hline & & & Participant & Size (gender) & $\begin{array}{c}\text { Grade } \\
\text { (country) }\end{array}$ & Collecting & Analyzing & \\
\hline 1 & $\begin{array}{l}\text { Ahmavaara and } \\
\text { Houston } \\
(2007)\end{array}$ & $\begin{array}{l}\text { The Effects of Selective Schooling and } \\
\text { Self-concept on Adolescents' Academic } \\
\text { Aspiration: An Examination of Dweck's } \\
\text { Self-Theory }\end{array}$ & Student & $\begin{array}{c}\mathrm{N}=856 \\
(\mathrm{M}=427, \mathrm{~F}=429)\end{array}$ & $\begin{array}{c}\mathrm{M} \\
\text { (Britain) }\end{array}$ & Q & $\begin{array}{c}\text { DS \& RA \& } \\
\text { PMA }\end{array}$ & Cause \\
\hline 2 & $\begin{array}{l}\text { Aronson, Fried, } \\
\text { and Good } \\
\quad(2002)\end{array}$ & $\begin{array}{l}\text { Reducing the Effects of Stereotype Threat } \\
\text { on African American College Students by } \\
\text { Shaping Theories of Intelligence }\end{array}$ & Student & $\mathrm{N}=79$ & $\begin{array}{c}\mathrm{U} \\
(\mathrm{USA})\end{array}$ & Q & $\begin{array}{c}\text { ANOVA \& } \\
\text { FA }\end{array}$ & Cause \\
\hline 3 & $\begin{array}{l}\text { Blackwell, } \\
\text { Trzesniewski, } \\
\text { and Dweck } \\
\text { (2007) }\end{array}$ & $\begin{array}{l}\text { Implicit Theories of Intelligence Predict } \\
\text { Achievement Across an Adolescent } \\
\text { Transition: A Longitudinal Study and an } \\
\text { Intervention }\end{array}$ & Student & 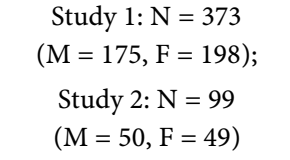 & $\begin{array}{c}\mathrm{M} \\
\text { (USA) }\end{array}$ & Q & RA \& HLM & Cause \\
\hline 4 & $\begin{array}{c}\text { Chen and Pajares } \\
\text { (2010) }\end{array}$ & $\begin{array}{l}\text { Implicit Theories of Ability of Grade } 6 \\
\text { Science Students: Relation to } \\
\text { Epistemological Beliefs and Academic } \\
\text { Motivation and Achievement in Science }\end{array}$ & Student & $\mathrm{N}=508$ & $\begin{array}{c}\mathrm{E} \\
(\mathrm{USA})\end{array}$ & Q & DS \& PMA & Cause \\
\hline 5 & $\begin{array}{l}\text { Claro, Paunesku, } \\
\text { and Dweck } \\
\quad(2016)\end{array}$ & $\begin{array}{l}\text { Growth Mindset Tempers the Effect of } \\
\text { Poverty on Academic Achievement }\end{array}$ & Student & $N=168,203$ & $\begin{array}{c}\mathrm{E} \\
\text { (Chile) }\end{array}$ & Q & HLM & $\begin{array}{c}\text { Cause/ } \\
\text { Mediator }\end{array}$ \\
\hline 6 & $\begin{array}{l}\text { Dupeyrat and } \\
\text { Mariné } \\
(2005)\end{array}$ & $\begin{array}{l}\text { Implicit Theories of Intelligence, Goal } \\
\text { Orientation, Cognitive Engagement, and } \\
\text { Achievement: A Test of Dweck's Model } \\
\text { with Returning to School Adults }\end{array}$ & Student & $\begin{array}{c}\mathrm{N}=76 \\
(\mathrm{M}=31, \mathrm{~F}=45)\end{array}$ & $\begin{array}{c}\mathrm{M} \\
\text { (France) }\end{array}$ & Q & FA & No \\
\hline 7 & $\begin{array}{l}\text { Fonseca et al. } \\
\qquad(2009)\end{array}$ & $\begin{array}{l}\text { When Depression Mediates the } \\
\text { Relationship Between Entity Beliefs and } \\
\text { Performance }\end{array}$ & Student & $\begin{array}{c}\mathrm{N}=353 \\
(\mathrm{M}=175, \mathrm{~F}=178)\end{array}$ & $\begin{array}{c}\mathrm{M} \\
\text { (France) }\end{array}$ & $\mathrm{T} \& \mathrm{Q}$ & RA & Cause \\
\hline 8 & $\begin{array}{l}\text { Gonida, } \\
\text { Kiosseoglou, and } \\
\text { Leondari } \\
\text { (2006) }\end{array}$ & $\begin{array}{l}\text { Implicit Theories of Intelligence, } \\
\text { Perceived Academic Competence, and } \\
\text { School Achievement: Testing } \\
\text { Alternative Models }\end{array}$ & Student & $\begin{array}{l}\text { First phase: } \mathrm{N}=232 \\
(\mathrm{M}=115, \mathrm{~F}=117) \\
\text { Second phase: } \mathrm{N}=187 \\
\quad(\mathrm{M}=91, \mathrm{~F}=96)\end{array}$ & $\begin{array}{c}\text { E \& M } \\
\text { (Greece) }\end{array}$ & Q & ANOVA & Outcome \\
\hline 9 & $\begin{array}{l}\text { Good, Aronson, } \\
\text { and Inzlicht } \\
\text { (2003) }\end{array}$ & $\begin{array}{l}\text { Improving Adolescents' Standardized } \\
\text { Test Performance: An Intervention to } \\
\text { Reduce the Effects of } \\
\text { Stereotype Threat }\end{array}$ & Student & $\begin{array}{c}N=138 \\
(M=76, F=62)\end{array}$ & $\begin{array}{c}\mathrm{M} \\
\text { (USA) }\end{array}$ & I & ANOVA & Cause \\
\hline 10 & $\begin{array}{l}\text { Cury, Fonseca, } \\
\text { Zahn, and Elliot } \\
\quad(2008)\end{array}$ & $\begin{array}{c}\text { Implicit Theories and IQ Test } \\
\text { Performance: A Sequential Mediational } \\
\text { Analysis }\end{array}$ & Student & $\begin{array}{l}\text { Study1: } \mathrm{N}=47 \\
(\mathrm{M}=23, \mathrm{~F}=24) \\
\text { Study } 2: \mathrm{N}=86 \\
(\mathrm{M}=41, \mathrm{~F}=45)\end{array}$ & $\begin{array}{c}\mathrm{M} \\
\text { (France) }\end{array}$ & Q & $\begin{array}{c}\text { DS \& FA \& } \\
\text { RA }\end{array}$ & Cause \\
\hline 11 & $\begin{array}{l}\text { Heyman and } \\
\text { Dweck } \\
(1998)\end{array}$ & $\begin{array}{l}\text { Children's Thinking about Traits: } \\
\text { Implications for Judgments of the Self } \\
\text { and Others }\end{array}$ & Student & $\begin{array}{l}\text { Study } 1: N=86 \\
(M=40, F=46) \\
\text { Study } 2: N=116 \\
(M=58, F=58)\end{array}$ & $\begin{array}{c}\mathrm{E} \\
(\mathrm{USA})\end{array}$ & I & $\begin{array}{c}\text { FA \& } \\
\text { ANOVA }\end{array}$ & Cause \\
\hline 12 & $\begin{array}{l}\text { Leondari and } \\
\text { Gialamas } \\
\text { (2002) }\end{array}$ & $\begin{array}{c}\text { Implicit Theories, Goal Orientations, and } \\
\text { Perceived Competence: Impact on } \\
\text { Students' Achievement } \\
\text { Behavior }\end{array}$ & Student & $\begin{array}{c}\mathrm{N}=451 \\
(\mathrm{M}=204, \mathrm{~F}=247)\end{array}$ & $\begin{array}{c}\text { E \& M } \\
\text { (Greece) }\end{array}$ & Q & FA & $\begin{array}{l}\text { Cause/ } \\
\mathrm{No}^{1}\end{array}$ \\
\hline 13 & $\begin{array}{l}\text { Mouratidis, } \\
\text { Michou, and } \\
\text { Vassiou } \\
\text { (2017) }\end{array}$ & $\begin{array}{l}\text { Adolescents' Autonomous Functioning } \\
\text { and Implicit Theories of Ability as } \\
\text { Predictors of Their School Achievement } \\
\text { and Week-to-Week Study Regulation } \\
\text { and Well-being }\end{array}$ & Student & $\begin{array}{c}\mathrm{N}=179 \\
(\mathrm{M}=64, \mathrm{~F}=115)\end{array}$ & $\begin{array}{c}\mathrm{M} \\
\text { (Greece) }\end{array}$ & Q & $\begin{array}{c}\text { DS \& FA \& } \\
\text { RA }\end{array}$ & Mediator \\
\hline
\end{tabular}




\section{Continued}

\begin{tabular}{|c|c|c|c|c|c|c|c|c|}
\hline 14 & $\begin{array}{l}\text { Mueller and } \\
\text { Dweck } \\
(1998)\end{array}$ & $\begin{array}{l}\text { Praise for Intelligence Can Undermine } \\
\text { Children's Motivation and Performance }\end{array}$ & Student & $\begin{array}{c}\text { Study } 1: \mathrm{N}=128 \\
(\mathrm{M}=58, \mathrm{~F}=70) ; \\
\text { Study } 2: \mathrm{N}=51 \\
(\mathrm{M}=25, \mathrm{~F}=26) ; \\
\text { Study } 3: \mathrm{N}=88 \\
(\mathrm{M}=40, \mathrm{~F}=48) ; \\
\text { Study } 4: \mathrm{N}=51 \\
(\mathrm{M}=22, \mathrm{~F}=29) ; \\
\text { Study } 5: \mathrm{N}=46 \\
(\mathrm{M}=20, \mathrm{~F}=26) ; \\
\text { Study } 6: \mathrm{N}=48 \\
(\mathrm{M}=25, \mathrm{~F}=23)\end{array}$ & $\begin{array}{c}\mathrm{E} \\
(\mathrm{USA})\end{array}$ & SPM & $\begin{array}{l}\text { ANOVA, } \\
\text { T-t, Chi-s } \\
\text { A. }\end{array}$ & Cause \\
\hline 15 & $\begin{array}{l}\text { Robins and Pals } \\
\text { (2002) }\end{array}$ & $\begin{array}{l}\text { Implicit Self-Theories in the Academic } \\
\text { Domain: Implications for Goal } \\
\text { Orientation, Attributions, Affect, and } \\
\text { Self-Esteem Change }\end{array}$ & Student & $\mathrm{N}=508(\mathrm{M}=224, \mathrm{~F}=284)$ & $\begin{array}{c}\mathrm{U} \\
(\mathrm{USA})\end{array}$ & Q & $\begin{array}{l}\text { FA \& RA \& } \\
\text { PMA }\end{array}$ & No \\
\hline 16 & $\begin{array}{l}\text { Romero, Master, } \\
\text { Paunesku, } \\
\text { Dweck, and } \\
\text { Gross (2014) }\end{array}$ & $\begin{array}{c}\text { Academic and Emotional Functioning in } \\
\text { Middle School: The Role of Implicit } \\
\text { Theories }\end{array}$ & Student & $\mathrm{N}=115(\mathrm{M}=48, \mathrm{~F}=67)$ & $\begin{array}{c}\mathrm{M} \\
\text { (USA) }\end{array}$ & $\mathrm{Q}$ & HLM & Cause \\
\hline 17 & $\begin{array}{l}\text { Zeng, Hou, and } \\
\text { Peng (2016) }\end{array}$ & $\begin{array}{l}\text { Effect of Growth Mindset on School } \\
\text { Engagement and Psychological } \\
\text { Well-Being of Chinese Primary and } \\
\text { Middle School Students: The Mediating } \\
\text { Role of Resilience }\end{array}$ & Student & $\mathrm{N}=1260(\mathrm{M}=658, \mathrm{~F}=602)$ & $\begin{array}{l}\text { E \& M } \\
\text { (China) }\end{array}$ & Q & SEM & Cause \\
\hline
\end{tabular}

${ }^{1}$ The reason this study has both "cause" and "no" roles is that authors mention that "incremental beliefs were not related to academic achievement. An explanation for this finding might be that incremental beliefs influence achievement indirectly through the adoption of a specific goal orientation."

Table 2. The role of teachers' mindsets in students' academic achievement.

\begin{tabular}{|c|c|c|c|c|c|c|c|c|}
\hline & \multirow{2}{*}{$\begin{array}{l}\text { Authors } \\
\text { (year) }\end{array}$} & \multirow{2}{*}{ Title } & \multicolumn{3}{|c|}{ Sample } & \multicolumn{2}{|c|}{$\begin{array}{l}\text { Method (see } \\
\text { Appendix) }\end{array}$} & \multirow{2}{*}{$\begin{array}{l}\text { Role of } \\
\text { Mindset }\end{array}$} \\
\hline & & & Participant & Size (gender) & $\begin{array}{c}\text { Grade } \\
\text { (country) }\end{array}$ & Collecting & Analyzing & \\
\hline 1 & $\begin{array}{l}\text { Jonsson and } \\
\text { Beach (2012) }\end{array}$ & $\begin{array}{l}\text { Predicting the Use of Praise among } \\
\text { Pre-Service Teachers: The Influence } \\
\text { of Implicit Theories of Intelligence, } \\
\text { Social Comparison and Stereotype } \\
\text { Acceptance }\end{array}$ & Teacher & $\begin{array}{l}\text { Study } 1: \mathrm{N}=176 \\
\begin{array}{c}(\mathrm{M}=23, \mathrm{~F}=151) \\
\text { Study } 2: \mathrm{N}=151 \\
(\mathrm{M}=10, \mathrm{~F}=140 \\
1 \text { missing })\end{array}\end{array}$ & $\begin{array}{c}\text { E \& M } \\
\text { (Sweden) }\end{array}$ & Q & RA \& FA & Cause \\
\hline 2 & $\begin{array}{l}\text { Kärkkäinen and } \\
\text { Räty (2010) }\end{array}$ & $\begin{array}{l}\text { Parents' and Teachers' Views of the } \\
\text { Child's Academic Potential }\end{array}$ & Teacher & $\begin{array}{c}\text { Parent: } \mathrm{N}=97 \\
(\mathrm{M}=46, \mathrm{~F}=50,1 \text { missing }) ; \\
\text { Teacher: } \mathrm{N}=8 \\
(\mathrm{M}=3, \mathrm{~F}=5)\end{array}$ & $\begin{array}{c}\mathrm{E} \\
\text { (Finland) }\end{array}$ & Q & ANOVA & $\begin{array}{l}\text { Cause/ } \\
\text { Mediator }\end{array}$ \\
\hline 3 & $\begin{array}{l}\text { Kärkkäinen, } \\
\text { Räty, and } \\
\text { Kasanen (2010) }\end{array}$ & $\begin{array}{c}\text { How Are Children's Perceptions of } \\
\text { the Malleability of Their Academic } \\
\text { Competencies Related to Their } \\
\text { Teachers' and Parents' Views? }\end{array}$ & Teacher & $\begin{array}{c}\text { Student: } \mathrm{N}=103 \\
(\mathrm{M}=51, \mathrm{~F}=52) ; \\
\text { Parent: } \mathrm{N}=97 \\
(\mathrm{M}=46, \mathrm{~F}=50 \\
1 \text { missing); Teacher: } \mathrm{N}=8 \\
(\mathrm{M}=3, \mathrm{~F}=5)\end{array}$ & $\begin{array}{c}\mathrm{E} \\
\text { (Finland) }\end{array}$ & Q & FA & Cause \\
\hline 4 & $\begin{array}{c}\text { Schmidt, } \\
\text { Shumow, and } \\
\text { Kackar-Cam } \\
\text { (2015) }\end{array}$ & $\begin{array}{l}\text { Exploring Teacher Effects for } \\
\text { Mindset Intervention Outcomes in } \\
\text { Seventh-Grade Science Classes }\end{array}$ & Teacher & $\begin{array}{c}\text { Student: } \mathrm{N}=160 \\
(\mathrm{M}=67, \mathrm{~F}=93) \\
\text { Teachers: } \mathrm{N}=2(\mathrm{~F}=2)\end{array}$ & $\begin{array}{c}\mathrm{M} \\
\text { (USA) }\end{array}$ & $O \& Q$ & $\begin{array}{l}\text { FA \& } \\
\text { B-S-A }\end{array}$ & Cause \\
\hline 5 & $\begin{array}{l}\text { Shim, Cho, and } \\
\text { Cassady (2013) }\end{array}$ & $\begin{array}{c}\text { Goal Structures: The Role of } \\
\text { Teachers' Achievement Goals and } \\
\text { Theories of Intelligence }\end{array}$ & Teacher & $\mathrm{N}=209(\mathrm{M}=45, \mathrm{~F}=164)$ & $\begin{array}{c}\mathrm{E} \\
\text { (USA) }\end{array}$ & S & $\begin{array}{l}\text { FA \& RA \& } \\
\text { Chi-s A }\end{array}$ & Cause \\
\hline
\end{tabular}


Apart from the intermediate variables outlined above, studies illustrated that mindset could also predict academic achievement by the mediation of resilience, socioeconomic strata and attribution. A nationwide study in Chile (Claro, Paunesku, \& Dweck, 2016), which examined 75\% of all tenth graders in Chile's public schools, showed how a growth mindset promoted academic learning, while a fixed mindset hindered it; "a growth mindset is a comparably strong predictor of achievement and... exhibits a positive relationship with achievement across all of the socioeconomic strata" (p. 8664). Similar results in line with Dweck's theory have been found with smaller samples in the United States (Chen \& $\mathrm{Pa}$ jares, 2010), China (Zeng, Hou, \& Peng, 2016), France (Cury, Fonseca, Zahn, \& Elliot, 2008), and Greece (Mouratidis, Michou, \& Vassiou, 2017). In contrast to a growth mindset, a fixed mindset "focuses individuals on avoiding demonstrations of inability" and "leads to decreased performance" (Cury et al., 2008, p. 789). The epistemological belief in scientific knowledge represents another interesting middle variable directly related to mindset, which in turn is directly related to science achievement as well as self-efficacy, and task-goal orientation (Chen \& Pajares, 2010). These notions also supported Dweck's (2002) argument that "children's competence-related beliefs have their strongest direct effects on performance" (p. 108). Compared with examples outlined above, a study without any intermediate variable, such as the American study by Romero, Master, Paunesku, Dweck, and Gross (2014), illustrated the significantly positive role of a growth mindset in improving course grades in academic subjects. Earlier studies have also found a negative effect of fixed mindsets on achievement. For example, Heyman and Dweck (1998) found that American second graders' low achievement was related to "belief of trait stability," which might be regarded as a fixed mindset.

\subsection{Mindset as a Mediator}

Two studies have found that mindset also plays the role of mediator. In addition to the causal role, Claro et al. (2016) highlighted that mindset could play the role of mediator and link the relationship between socioeconomic strata and achievement. Specifically, students from lower-income families who had a growth mindset exhibited higher academic performance because a growth mindset "appreciably buffered against the deleterious effects of poverty on achievement" (p. 8664). In other words, students' mindsets might reinforce the impact of a structural situation on a systemic level, which in turn affects achievement. A Greek study indicated that mindset was found to moderate the week-to-week relation of autonomous functioning to study effort and homework procrastination; it also affected student well-being, such as subjective vitality, and feelings of depression and thereby had a direct influence on academic achievement (Mouratidis et al., 2017). For example, a fixed mindset demonstrated lower mean levels of study effort, higher amounts of homework, and poorer grades.

Consistent with Butler's (2000) conclusion, although the author did not men- 
tion the relationship between mindset and academic achievement directly, students' mindset mediated "the effects of different kinds of information" (p. 974) on students' inferences about their ability level, including "moderating inferences from performance trends" and "the perceived diagnosticity of temporal versus normative feedback for self-appraisal."

\subsection{Mindset as an Outcome}

Students' mindset as an outcome means that students adopt and develop their mindsets as a result of their academic achievement. Although there is only one article to support this result, it deserves to be mentioned: a Greek study, by Gonida, Kiosseoglou, and Leondari (2006), which tested alternative models for mindset, perceived academic competence, and school achievement. Authors found that achievement determined the adoption of a particular mindset through the mediation of perceived competence. Specifically, the adoption of a particular mindset was found to depend on prior achievement level. For example, high achievers' mindset was significantly more incremental than that of medium and low achievers.

\subsection{Mindset without an Evident Role}

Interestingly, both French (Dupeyrat \& Mariné, 2005) and Greek (Leondari et al., 2002) studies have emphasized that the correlation between mindset and achievement is not significant. By examining 76 French students enrolled in a special one-year program, Dupeyrat and Mariné (2005) amassed data suggesting that mastery goals have a positive influence on academic achievement, but mindset "on goal orientation and cognitive engagement in learning failed to emerge" (p. 43). Thus, this study did not support Dweck's theory on the role of mindset in academic achievement. In the Greek study, Leondari et al. (2002) highlighted "incremental beliefs were not related to academic achievement" (p. 287). An explanation might be that incremental beliefs influenced achievement indirectly through the adoption of a specific goal orientation. In other words, mindset was not likely to have any direct impact on achievement. In an American study, Robins and Pals (2002) analyzed Scholastic Assessment Test (SAT) scores and Grade Point Averages (GPAs) of 508 undergraduate students of the University of California at Berkeley, and found that students' perceived performance did not differ based on whether a student had a fixed or a growth mindset. Furthermore, students with different mindsets may have different academic abilities, which "did not translate into higher achievement" (p. 323).

In summary, based on the current research, students' mindsets play various roles in academic achievement. Most of the research reviewed here provides support for a causal role in line with Dweck's theory, although some studies indicate a mediator role. Studies have also indicated some contradictory results: Mindset might be an outcome of previous academic achievement, and it seems that in some cases, mindset might not have an impact on students' achievement. 


\section{The Role of Teachers' Mindsets in Students' Academic Achievement}

Based on our review, the role of teachers' mindsets in student academic achievement (Table 2) will be discussed from two perspectives: teachers' mindset as a cause in students' academic achievement and teachers' mindset as a mediator in academic achievement.

\subsection{Mindset as a Cause}

Five articles (Table 2) were identified to support the role of teachers' mindset as a cause of students' academic achievement. By analyzing quantitative data collected from American seventh-grade science students $(\mathrm{N}=160)$ and their two teachers, Schmidt, Shumow, and Kackar-Cam (2015) found that teachers played a critically important role in supporting classroom intervention. In this study, students participated in a Brainology intervention program, while teachers' classroom interaction was observed. The study found that Brainology had a positive, but short-term impact on students' academic achievement in science. The influence of the intervention was sustained over several months among students whose teacher adopted growth mindset language and messages in the classroom. However, for students whose teacher held a fixed mindset and delivered fixed mindset messages in the classroom, the impact of the intervention did not last, and students' achievement was even lowered. Interestingly, despite similarities in the teachers' stated beliefs, teachers' related pedagogical practices produced different effects on their students' mindsets and achievement. By comparison, by adopting quasi-experimental pre-, post- and follow-up mixed-methods to investigate 33 secondary-school pupils in Scotland, Donohoe, Topping, and Hannah (2012) found that Brainology intervention initially "encouraged a growth mindset in the pupils, supporting the pre-post results of previous studies" (p. 653). However, no significant difference was found one year later between the intervention and the comparison groups in terms of examination performance. In other words, follow-up revealed that this shift in mindset was not sustained, which in the light of the study by Schmidt et al. (2013) could be explained by the teachers' role.

By investigating 103 Finnish third- and sixth-graders and their teachers, Kärkkäinen, Räty, and Kasanen (2010) found that both the children's interpersonal and intrapersonal perceptions of their potential for improvement tended to be related to their teachers' perceptions. And the correlation between children's interpersonal perceptions and teachers' perceptions was stronger than the intrapersonal ones, which may result from the fact that "teacher-given normative feedback is valuable and visible at school and specifically significant to the perceptions of school-aged children" (p. 569). Moreover, the authors' later research (Kärkkäinen \& Räty, 2010) spotlighted that teachers' perceptions of children's potential was less optimistic than that of parents in both the interpersonal and intrapersonal school subjects.

In predicting the use of praise among pre-service teachers, Jonsson and Beach 
(2012) conducted two studies involving 176 and 151 pre-service teachers respectively, and demonstrated that the pre-service teachers' preferences for using praise were positively related to their mindset. Moreover, the praise was an important factor in predicting students' achievement. In particular, process praise had positive effects on learning, while person praise could have negative effects. By investigating 209 primary- and secondary-school teachers in the mid-western region of the United States, Shim, Cho, and Cassady (2013) confirmed that, although the effect of teachers' mindset about students' intelligence was meager, a significant connection between teachers' mindset and classroom performance structure was found to have an interactive effect. In other words, nurturing teachers' mastery goals for teaching is beneficial to develop a learning environment in which students could achieve maximum learning and intellectual growth.

\subsection{Mindset as a Mediator}

Two studies from Finland indicate that a teacher's mindset could moderate the relationship between parents' mindset and their child's academic potential. Based on ratings of teachers' and parents' evaluation of children's potential for improvement in mathematics and the Finnish language, Kärkkäinen and Räty (2010) illustrated that the more optimistic children's parents are, the higher the confidence their children have in their own abilities, and thus, the greater academic potential they will have. The researchers also addressed that there was a "moderate and positive correlation" between the teachers' and parents' ratings of children's potential. This result was consistent with earlier research demonstrating that teachers' mindset for children's potential was related to the mindset of a child's mother (Räty, Kasanen, \& Kärkkäinen, 2006).

To summarize, although there is a limited amount of relevant research on teachers' mindsets in students' academic achievement, the available studies suggest that teachers' mindsets play the roles of both cause and mediator. And more studies find teachers' mindsets to be a causal factor than a mediator.

\section{Discussion}

This study reviewed current research to explore the role played by students' and teachers' mindsets in students' academic achievement. We reviewed the research on the relationship between mindset and academic achievement published from 1998 to 2017 and identified a total of 22 articles. We classified these into one of two categories based on the types of participants, and identified the role of mindset in students' academic achievement presented by respective authors.

Based on this review, it is evident that students' and teachers' mindsets are associated with students' academic achievement in various means. Specifically, students' mindsets play the roles of cause and mediator. Mindset can also be an outcome of students' academic achievement, while the roles played by teachers' mindsets were cause and mediator. It should also be emphasized that some studies found no link between mindset and achievement. Even though our review 
indicates somewhat contradictory findings compared to Dweck's (2000) theory, the results nevertheless provide interesting points for future empirical, theoretical, and practical discussions about how mindsets are developed and how they affect students' learning.

The result suggests that students' mindsets are related to their academic performance and that their academic achievement can be affected by intervention. Furthermore, it appears that in measuring the long-term effect of the intervention, teachers' mindset-related messages play an important role in the classroom. The result implies that mindsets are responsive to learning and achievement. In terms of theoretical applications, in order to obtain greater insight into academic achievement, we suggest that future research should: 1) explore the specific process that influence direct or indirect links between mindset and academic achievement, and 2) construct a structural model that demonstrates as accurately as possible the relationships between mindset and achievement for both students and teachers. As for practical applications, we suggest that educators develop a positive environment for fostering students' mindsets and improving students' academic achievement with effective intervention.

The present study has several limitations. First, the present literature includes research that focuses on both mindset and academic achievement. However, research that focuses just on mindset or just on academic achievement could be synthesized to prove our conclusion, especially in studies involving the same variables. For example, Yeager, Trzesniewski, Tirri, Nokelainen, and Dweck (2011) discussed the negative role in attribution of a fixed mindset and the positive role of intervention in emotion with a growth mindset. Moreover, some of the studies reviewed (e.g., Cury et al., 2008; Zeng et al., 2016; Mouratidis et al., 2017) indicated that attributions and emotions were important mediators between mindset and achievement. Secondly, we excluded studies that were not written in English. This may result in the exclusion of valuable research in other languages. Thirdly, the measure of academic achievement in the present study is not strictly based on grades. In some of our research (Ahmavaara \& Houston, 2007; Jonsson \& Beach, 2012; Shim, Cho, \& Cassady, 2013), the achievement outcome was not explicitly stated in the form of grade points, which may result in the ambiguity or the non-normalization of academic achievement to some extent.

Despite the potential limitations of the present review, it has considerable strengths. First, it represents the first review to discuss explicitly the role of students' and teachers' mindsets in student learning, which illustrates the direct and indirect relationships between mindset and academic achievement. Second, the review brings out for the first time the role of mindset in learning from three different perspectives-as cause, mediator, and outcome-and may shed light on another angle from which to enrich the research on mindset. Third, the study not only demonstrates the function of students' mindsets in learning, but also that of teachers' mindsets, thereby providing valuable resources for scholars and educators to examine teachers' classroom interaction and pedagogical thinking 
from the view of mindsets in order to improve students' performance.

\section{References}

Ahmavaara, A., \& Houston, D. M. (2007). The Effects of Selective Schooling and SelfConcept on Adolescents' Academic Aspiration: An Examination of Dweck's SelfTheory. British Journal of Educational Psychology, 77, 613-632. https://doi.org/10.1348/000709906X120132

Aronson, J., Fried, C. B., \& Good, C. (2002). Reducing the Effects of Stereotype Threat on African American College Students by Shaping Theories of Intelligence. Journal of EXperimental Social Psychology, 38, 113-125. https://doi.org/10.1006/jesp.2001.1491

Blackwell, L. S., Trzesniewski, K. H., \& Dweck, C. S. (2007). Implicit Theories of Intelligence Predict Achievement across an Adolescent Transition: A Longitudinal Study and an Intervention. Child Development, 78, 246-263. https://doi.org/10.1111/j.1467-8624.2007.00995.x

Burnette, J. L., O’Boyle, E. H., VanEpps, E. M., Pollack, J. M., \& Finkel, E. J. (2013). Mind-Sets Matter: A Meta-Analytic Review of Implicit Theories and Self-Regulation.

Butler, R. (2000). Making Judgments about Ability: The Role of Implicit Theories of Ability in Moderating Inferences from Temporal and Social Comparison Information.

Chen, J. A., \& Pajares, F. (2010). Implicit Theories of Ability of Grade 6 Science Students: Relation to Epistemological Beliefs and Academic Motivation and Achievement in Science. Contemporary Educational Psychology, 35, 75-87. https://doi.org/10.1016/j.cedpsych.2009.10.003

Claro, S., Paunesku, D., \& Dweck, C. S. (2016). Growth Mindset Tempers the Effects of Poverty on Academic Achievement. Proceedings of the National Academy of Sciences, 113, 8664-8668. https://doi.org/10.1073/pnas.1608207113

Cury, F., Da Fonseca, D., Zahn, I., \& Elliot, A. (2008). Implicit Theories and IQ Test Performance: A Sequential Mediational Analysis. Journal of Experimental Social Psychology, 44, 783-791. https://doi.org/10.1016/j.jesp.2007.07.003

Da Fonseca, D., Cury, F., Santos, A., Payen, V., Bounoua, L., Brisswalter, J., \& Deruelle, C. (2009). When Depression Mediates the Relationship between Entity Beliefs and Performance. Child Psychiatry \& Human Development, 40, 213-222.

https://doi.org/10.1007/s10578-008-0122-9

Donohoe, C., Topping, K., \& Hannah, E. (2012). The Impact of an Online Intervention (Brainology) on the Mindset and Resiliency of Secondary School Pupils: A Preliminary Mixed Methods Study. Educational Psychology, 32, 641-655. https://doi.org/10.1080/01443410.2012.675646

Dupeyrat, C., \& Mariné, C. (2005). Implicit Theories of Intelligence, Goal Orientation, Cognitive Engagement, and Achievement: A Test of Dweck's Model with Returning to School Adults. Contemporary Educational Psychology, 30, 43-59.

Dweck, C. S. (2000). Self-Theories: Their Role in Motivation, Personality, and Development. Psychology Press.

Dweck, C. S. (2002). The Development of Ability Conceptions. Development of Achievement Motivation, 17, 57-88.

Dweck, C. S. (2006). Mindset: The New Psychology of Success. Random House.

Dweck, C. S. (2012). Mindsets and Human Nature: Promoting Change in the Middle East, the Schoolyard, the Racial Divide, and Willpower. American Psychologist, 67, 614. https://doi.org/10.1037/a0029783

Dweck, C. S., \& Bush, E. S. (1976). Sex Differences in Learned Helplessness: I. Differential 
Debilitation with Peer and Adult Evaluators. Developmental Psychology, 12, 147. https://doi.org/10.1037/0012-1649.12.2.147

Dweck, C. S., \& Leggett, E. L. (1988). A Social-Cognitive Approach to Motivation and Personality. Psychological Review, 95, 256. https://doi.org/10.1037/0033-295X.95.2.256

Dweck, C. S., Davidson, W., Nelson, S., \& Enna, B. (1978). Sex Differences in Learned Helplessness: II. The Contingencies of Evaluative Feedback in the Classroom and III. An Experimental Analysis. Developmental Psychology, 14, 268. https://doi.org/10.1037/0012-1649.14.3.268

Esparza, J., Shumow, L., \& Schmidt, J. A. (2014). Growth Mindset of Gifted Seventh Grade Students in Science. NCSSSMST Journal, 19, 6-13.

Gonida, E., Kiosseoglou, G., \& Leondari, A. (2006). Implicit Theories of Intelligence, Perceived Academic Competence, and School Achievement: Testing Alternative Models. The American Journal of Psychology, 119, 223-238. https://doi.org/10.2307/20445336

Good, C., Aronson, J., \& Inzlicht, M. (2003). Improving Adolescents' Standardized Test Performance: An Intervention to Reduce the Effects of Stereotype Threat. Journal of Applied Developmental Psychology, 24, 645-662.

Gutshall, C. A. (2013). Teachers' Mindsets for Students with and without Disabilities. Psychology in the Schools, 50, 1073-1083. https://doi.org/10.1002/pits.21725

Gutshall, C. A. (2014). Pre-Service Teachers' Mindset Beliefs about Student Ability. Electronic Journal of Research in Educational Psychology, 12, 785-802.

Heyman, G. D., \& Dweck, C. S. (1998). Children's Thinking about Traits: Implications for Judgments of the Self and Others. Child Development, 69, 391-403. https://doi.org/10.1111/j.1467-8624.1998.tb06197.x

Jonsson, A. C., \& Beach, D. (2012). Predicting the Use of Praise among Pre-Service Teachers: The Influence of Implicit Theories of Intelligence, Social Comparison and Stereotype Acceptance. Education Inquiry, 3, 259-281.

https://doi.org/10.3402/edui.v3i2.22033

Kärkkäinen, R., \& Räty, H. (2010). Parents' and Teachers' Views of the Child's Academic Potential. Educational Studies, 36, 229-232. https://doi.org/10.1080/03055690903162424

Kärkkäinen, R., Räty, H., \& Kasanen, K. (2010). How Are Children's Perceptions of the Malleability of Their Academic Competencies Related to Their Teachers' and Parents' Views? Social Psychology of Education, 13, 557-573. https://doi.org/10.1007/s11218-010-9126-y

Leondari, A., \& Gialamas, V. (2002). Implicit Theories, Goal Orientations, and Perceived Competence: Impact on Students' Achievement Behavior. Psychology in the Schools, 39, 279-291. https://doi.org/10.1002/pits.10035

Levy, S. R., \& Dweck, C. S. (1999). The Impact of Children's Static versus Dynamic Conceptions of People on Stereotype Formation. Child Development, 70, 1163-1180. https://doi.org/10.1111/1467-8624.00085

Mouratidis, A., Michou, A., \& Vassiou, A. (2017). Adolescents' Autonomous Functioning and Implicit Theories of Ability as Predictors of Their School Achievement and Weekto-Week Study Regulation and Well-Being. Contemporary Educational Psychology, 48, 56-66.

Mueller, C. M., \& Dweck, C. S. (1998). Praise for Intelligence Can Undermine Children's Motivation and Performance. Journal of Personality and Social Psychology, 75, 33.

https://doi.org/10.1037/0022-3514.75.1.33 
O’Rourke, E., Haimovitz, K., Ballweber, C., Dweck, C., \& Popović, Z. (2014). Brain Points: A Growth Mindset Incentive Structure Boosts Persistence in an Educational Game. In Proceedings of the SIGCHI Conference on Human Factors in Computing Systems (pp. 3339-3348). New York, NY: ACM. https://doi.org/10.1145/2556288.2557157

Räty, H., Kasanen, K., \& Kärkkäinen, R. (2006). School Subjects as Social Categorisations. Social Psychology of Education, 9, 5-25. https://doi.org/10.1007/s11218-005-2439-6

Rissanen, I., Kuusisto, E., Hanhimäki, E., \& Tirri, K. (2016). Teachers’ Implicit Meaning Systems and Their Implications for Pedagogical Thinking and Practice: A Case Study from Finland. Scandinavian Journal of Educational Research, 1-14. https://doi.org/10.1080/00313831.2016.1258667

Robins, R. W., \& Pals, J. L. (2002). Implicit Self-Theories in the Academic Domain: Implications for Goal Orientation, Attributions, Affect, and Self-Esteem Change. Self and Identity, 1, 313-336. https://doi.org/10.1080/15298860290106805

Romero, C., Master, A., Paunesku, D., Dweck, C. S., \& Gross, J. J. (2014). Academic and Emotional Functioning in Middle School: The Role of Implicit Theories. Emotion, 14, 227. https://doi.org/10.1037/a0035490

Schmidt, J. A., Shumow, L., \& Kackar-Cam, H. (2015). Exploring Teacher Effects for Mindset Intervention Outcomes in Seventh-Grade Science Classes. Middle Grades Research Journal, 10, 17.

Shim, S. S., Cho, Y., \& Cassady, J. (2013). Goal Structures: The Role of Teachers' Achievement Goals and Theories of Intelligence. The Journal of Experimental Education, 81, 84-104. https://doi.org/10.1080/00220973.2011.635168

Tirri, K., \& Kujala, T. (2016). Students' Mindsets for Learning and Their Neural Underpinnings. Psychology, 7, 1231. https://doi.org/10.4236/psych.2016.79125

Yeager, D. S., \& Walton, G. M. (2011). Social-Psychological Interventions in Education: They're Not Magic. Review of Educational Research, 81, 267-301. https://doi.org/10.3102/0034654311405999

Yeager, D. S., Trzesniewski, K. H., Tirri, K., Nokelainen, P., \& Dweck, C. S. (2011). Adolescents' Implicit Theories Predict Desire for Vengeance after Peer Conflicts: Correlational and Experimental Evidence. Developmental Psychology, 47, 1090. https://doi.org/10.1037/a0023769

Zeng, G., Hou, H., \& Peng, K. (2016). Effect of Growth Mindset on School Engagement and Psychological Well-Being of Chinese Primary and Middle School Students: The Mediating Role of Resilience. Frontiers in Psychology, 7, 1873.

https://doi.org/10.3389/fpsyg.2016.01873 
Appendix. Coding Legend for Table 1 \& Table 2

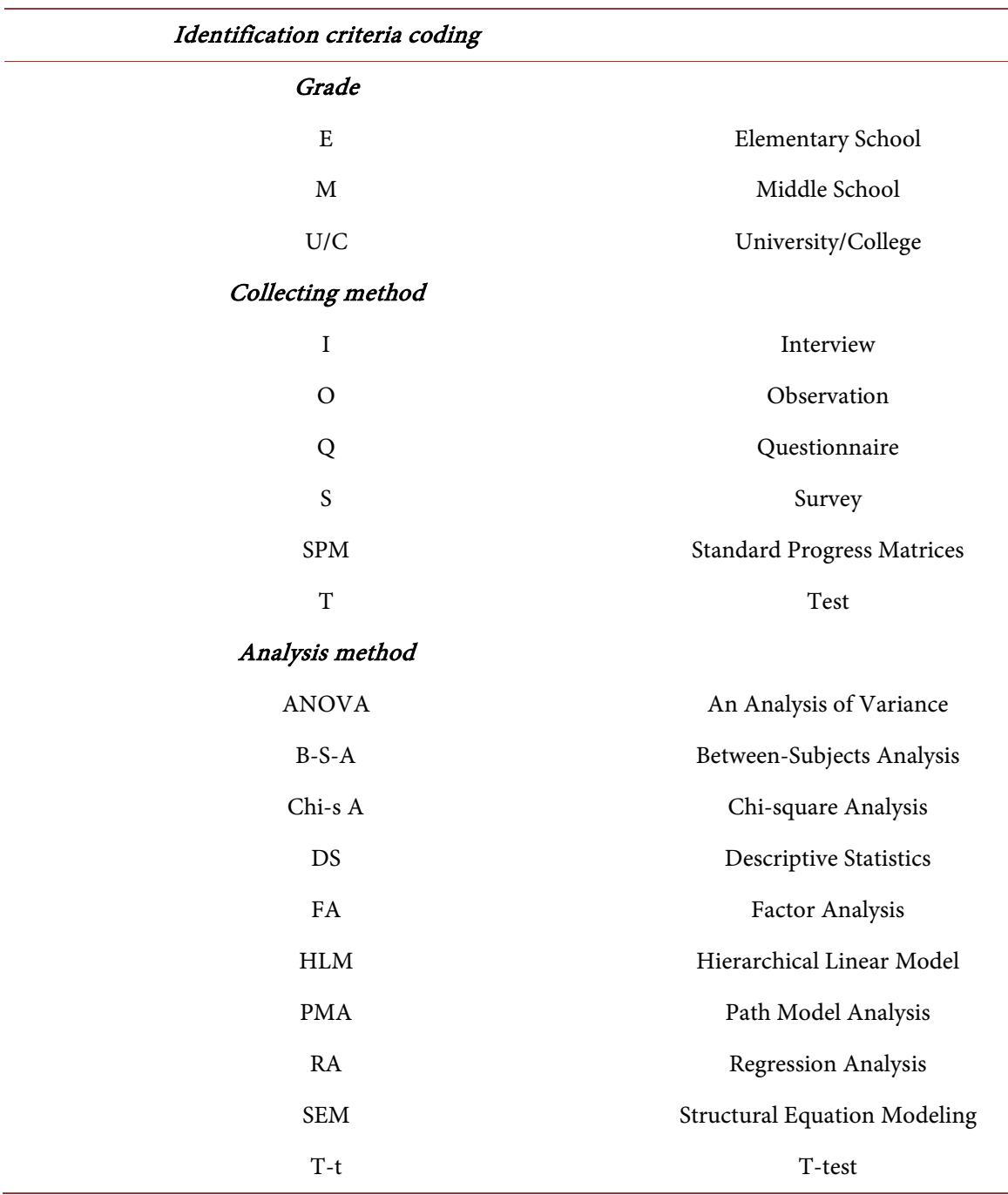

Submit or recommend next manuscript to SCIRP and we will provide best service for you:

Accepting pre-submission inquiries through Email, Facebook, LinkedIn, Twitter, etc. A wide selection of journals (inclusive of 9 subjects, more than 200 journals) Providing 24-hour high-quality service User-friendly online submission system Fair and swift peer-review system Efficient typesetting and proofreading procedure Display of the result of downloads and visits, as well as the number of cited articles Maximum dissemination of your research work

Submit your manuscript at: http://papersubmission.scirp.org/ Or contact psych@scirp.org 